\title{
Restrictions on Some Western Songs: a Counter Hegemony Effort by the West Java Regional Indonesian Broadcasting Commission
}

\author{
http://dx.doi.org/10.25008/jkiski.v5i2.380
}

\author{
Andre Ikhsano $^{1 *}$, Yolanda Stellarosa ${ }^{2}$ \\ ${ }^{1,2}$ Faculty of Communications Studies \\ LSPR Communication and Business Institute \\ Jl. Mas Mansur Kav. 35 Jakarta 10220 - Indonesia \\ *Corresponding author: andre.i@1spr.edu
}

Submitted: June 20, 2020, Revised: October 10, 2020, Accepted: December 13, 2020

Accredited by Kemristekdikti No. 30/E/KPT/2019

\begin{abstract}
Restriction on the broadcasting of 17 western songs considered full of sexual aspects in the Indonesian province of West Java has given rise to polemic and criticism. Various reactions, both negative and positive, emerged. Instead of supporting the restriction the Indonesian public appeared to blatantly oppose the policy made by the West Java Regional Indonesian Broadcasting Commission (KPID). It is interesting to analyze and study this phenomenon more deeply through the great concepts of Gramsci's counter hegemony. Of course, a mature and strategic counter hegemony is needed to counter western music hegemony in the country. The study of counter hegemony has not been widely discussed, especially when it comes to the counter of the counter hegemony itself and this can be the novelty of this study. This phenomenon is analyzed through critical perspective by conducting literature study in several online media sites related to the topic of this research. The results show that the counter hegemony which was not carried out systematically and strategically with regard to the restrictions on the broadcasting of 17 western songs in the province of West Java did not yield a fruit in the form of the hegemony's downfall. The hegemony of western songs remains strong. The failure of counter hegemony will strengthen the hegemony of western songs in Indonesia. For its part, it is necessary to have mature planning and strong collaboration between political society and civil society to make the counter hegemony run well in an attempt to undermine the hegemony.
\end{abstract}

Keywords: Hegemony, counter-hegemony, pop culture, resistance, western song

\section{Introduction}

The Decision of Komisi Penyiaran Indonesia Daerah (KPID) or Regional Indonesian Broadcasting Commission of West Java No. 480.215/KPID-Jabar/2019 has been much discussed and argued by KPID commissioners. Under the decision, KPID of West Java has restricted the broadcasting of 17 English songs, video clip, and any other form which can only be broadcast with specification D (dewasa/adults) in West Java from 22.00 WIB to 03.00 WIB. According to the head of KPID West Java, Dedeh
Fardiah, the reason behind the restriction is that the songs contain sexual aspects or obscene on the scene or lyric which cannot be consumed, especially by underage children in accordance with article 20 paragraph 1 and article 38 P3SPS (Arief, 2019). Dedeh Fardiah also said that the issuance of the decision was based on a prior review: "so we certainly based on the circular of the plenary meeting of the commissioners.

At the meeting, we reviewed various songs based on the public's complaints and the West Java KPID's monitoring and then we selected several 
songs,". The study and meetings began with a variety of complaints and concerns from the people of West Java about western songs featuring vulgar scenes. "We take the policy to limit it (the playback of the songs). In this context, the songs can only be aired from $10 \mathrm{pm}$ to $3 \mathrm{am}$. The policy applies to broadcasters in West Java. Broadcasting is supervised by the West Java KPID "(Pikiran Rakyat, 2019).

The songs which are subjected to the restriction are titled Dusk Till Dawn (Zayn Malik), Sangria Wine (Camila Cabello ft. Pharrell W), Mr Brightside (The Killers), Let Me ( Zayn Malik), Love Me Harder (Ariana Grande), Plot Twist (Marc E Bassy), Shape of You (Ed Sheeran), Overdose (Chris Brown ft. Agnez Mo), Makes Me Wonder (Maroon 5), That's What I Like (Bruno Mars), Fuck it I Don't Want You Back (Eamon), Bad Things (Camila Cabello ft. Machine), Versace on the Floor (Bruno Mars), Midsummer Madness (88 Rising), Wild Thoughts (DJ Khaled ft. Rihanna), Till it Hurts (Yellow Claw), Your Song (Rita Ora).

A variety of reactions also have appeared, thereby giving rise to some arguments, for example: Bruno Mars. Two of Bruno Mars's songs titled Versace on the Floor and That's What I like, are included in songs restriction. Bruno Mars was able to lodge his protest into jokes with sarcasm involving Ed Sheeran (which is among the 17 songs). In his tweet covered by online media Tribun News: "I was popular in Indonesia! Then (a) edsheeran appeared with the lyrics that were sick, obscene, and made us all get pinched! Thank you, Ed. Thank you very much", he insinuated in his first tweet, a few minutes later, Bruno Mars issued a follow-up note. "'I'm in love with the shape of you (I love your shape)?' Is that really (a)edsheeran? You are a monster! \& don't make me start discussing 'Thinking Out Loud'. You have no shame?" Finally, Bruno Mars called on the Indonesian public not to be equated with $\mathrm{Ed}$ Sheeran." Dear Indonesian, I gave you so many hits of 'Nothing on You', 'Just the Way You Are' \& 'Treasure'. Do not compare me with the sexual pervert" (Susanti, 2019). Not only Bruno Mars, but also negative-pitched reactions emerge, ranging from radio industry players and observers of domestic music because these restrictions can erode the freedom of expression.

Besides the negative reaction, the positive reaction supporting the circular of West Java KPID was seen as an oasis in an effort to fight or resist hegemony, especially western music hegemony in the country. Instead of supporting this resistance, the Indonesian society appears to oppose the policy in a clear and open manner. Contrary to the West
Java KPID policy, as if it was a form of defense of western music hegemony in the country. This is what researchers call a form of community resistance to the West Java KPID policy which can be said to be a form of resistance itself, but resistance to counter hegemony of western music in the country (not resistance to hegemony).

It is interesting to analyze and study this phenomenon (perhaps more precisely noumena) in depth through the great concepts of hegemony and Gramscian's counter hegemony. Basically, there have been many researches on hegemony, with the majority of them focusing on "western" hegemony on "east" in various aspects, including media. Hegemony may simply be assumed as a life-view, ideology and dominant class-thinking way of thinking to the public as a hegemonized class through institutional and individual ways so that unconsciously the unlucky class is unconscious of being colonized. So hegemony is:

\footnotetext{
"A group supremacy can be reflected in two ways; as a domination and as intellectual and moral leadership". In one hand, a social group that dominates opposition groups aims to "diminish" or rule over them" (Ikhsano \& Stellarosa, 2015)
}

Hegemony can be interpreted as a dominating action through various aspects, especially in research carried out through culture by the dominant (western) people to the inferior (Indonesian society) so that various kinds of cultures are imposed globally such as fashion, food, life style, music, films and so on, accepted willingly and voluntarily by the Indonesian people. In this case, media should be able to educate people with content or information conveyed, but in fact mass media also serve as a means of persuasion and propaganda which legitimates certain function and ideology practice (Stellarosa, 2017). Especially the capitalism ideology as mentioned by Berto (2018) that the meanings are commodified and eventually reduced before being contaminated by the capitalist ideology which only emphasizes on the principles of progress and recency (standardization), individualism (pseudo-individualism and social cement), and efficiency (fetishism).

Hegemony in the music sector in Indonesia has occurred since the 1960s. This certainly has a very strong and rooted impact on the hegemony itself, so there needs to be resistance or counter hegemony to the hegemony. Simple counter hegemony can be said to be a form of resistance to the hegemony itself through crisis hegemony and war of position. This stage of the counter hegemony has become a crucial point in this research. The previous study conducted by Ikhsano 
and Stellarosa (2015) shows that the failure of resistance or counter hegemony to a form of hegemony would actually make the hegemony stronger. This is a big assumption in this study.

Through critical perspective, this study saw that the restriction on the broadcasting of 17 western songs by West Java KPID as a counter hegemony seems to be unstructured, and to be not neat, thereby causing researchers to have concern about the failure of counter hegemony to western music in the country so that it would automatically strengthen the hegemony of western music in the homeland itself.

The impression of the unstructured counter hegemony at a glance can be seen from the rise of negative reactions from the public, both industry players and national music observers, to the restriction, so that it was not formed as Gramsci said to be collective will. A good collective will certainly requires very strong collaboration between elements of political will (the central government, regional government, central KPI, etc.) and civil society (general public, industry, observers, etc.) in carrying out counter hegemony movement. The failure of the counter hegemony is in turn expected to provide academic contributions in the form of novelty to the great concept of the counter hegemony.

From the exposure of the problems and urgency values above, the research aims to see the extent to which resistance of the Indonesian society (civil society) to the resistance or counter hegemony by the West Java KPID through its circular regarding the restriction on the broadcasting of 17 western songs to oppose the hegemony of western music in West Java works from Gramscian's perspective.

\section{Theoretical Framework}

There have been many researches on hegemony, including that conducted by Ali (2015). The importance of hegemony is illustrated by Ali's research which states that FRELIMO (Front for the Liberations of Mozambique)'s resistance to the Portuguese colonial rule requires very important attention to the practice of dialectic hegemony before to the aspect of domination. The attainment of domination without the practice of hegemony can be achieved but will always create resistance compared to the practice of hegemony first.

The other research was carried out by Rachar (2016) who emphasizes integration and compares Searle and Gramsci's thoughts on the construction of social life. Searle presents in detail how to analyze the formation of social entities from the aspect of agents while Gramsci's hegemony can be used to know the occurrence of differences in society into certain groups in constructing social life.

The next study was conducted by Robinson (2005). In his research on the hegemony, Robinson argued that hegemony, on a global perspective, originated from the theory of capitalism. In the beginning, hegemony only seemed to be suitable and focused on the scale of the country (internal state problems), then Gramscian's hegemony developed (because of globalization) to be transnational, especially transnational capitalist class. Transnational capitalist emphasizes or global capitalism as an actor in global hegemony is insisted by Rupert (2006), Rupert emphasizes that Gramscian's hegemony is still very relevant to be explored deeply to see how the relationship between power and structure (governance) as a whole.

The various studies above have led to the hegemony developing rapidly, not only focusing on the affairs of the state, but also globalizing. Hegemony can also be compared with other concepts and hegemony also requires collaboration from various elements (actors) to succeed. This is certainly very relevant to this research, namely how music hegemony works transnationally from the west pop culture to the east (Indonesia) with the big actor in the form of the global capitalism. So, in this case hegemony is not only seen at state level, but it is transnational and certainly requires collaboration between civil society and political will in conducting counter hegemony.

Hegemony is also seen as a very soft way of dictating various kinds of ideology without domination (via violence) so that the counter hegemony mechanism in Indonesia can be made possible through the restriction on the broadcasting of 17 songs by the West Java KPID without the element of domination that has a hard connotation. From the relevance above, the urgency value in the novelty aspect of this research is the failure of counter hegemony that occurs due to the unstructured counter hegemony strategy because it is not fully supported by the civil society.

\section{Material and Methodology}

The critical paradigm, as a big umbrella in this study, is in line with the theory of hegemony and Grasmcian's counter hegemony and its efforts in dismantling the pseudo reality that has been formed for a long time; meaning that western music hegemony in Indonesia has been going on for so long that the dismantling of consciousness in society is the main key in the critical paradigm.

In supporting the demolition, a deep approach is needed in the form of a qualitative approach with data collection in the form of 
literature observation from various kinds of online media coverage related to resistance to the restriction on western songs by the West Java KPID: palu-tribunnew.com (KPID Jawa Barat batasi penyiaran lagu berkonten vulgar, berikut tanggapan Bruno Mars Hingga KPID/West Java KPID limits the broadcasting of vulgar songs, following is Bruno Mars' response to KPID); merdeka.com (Jika masih ada, Soekarno mungkin larang konser Lady Gaga/If he was still alive, Soekarno might ban Lady Gaga's Concert); bisnis.tempo.co (Dianggap cabul, KPID Jawa Barat batasi jam tayang 17 lagu/Considered obscene, the West Java KPID limits the broadcast of 17 songs); ayobandung.com (Ini kata pengamat tentang larangan lagu barat oleh KPID/This is what observers say about the probihition of western songs by KPID).

The four online news reports above were taken from February 26 to May 1, 2019. The aspect of the relevance of the news regarding the elements in the counter hegemony theory of each online media site is the main consideration for the researcher in choosing the news. The analysis of the data used adopts the Gramscian counter hegemony theory in its effort to produce the goodness of critical research criteria including the historical situatedness of inquiry and stimulus action (praxis). The analysis of data for specifically used a social semiotics by Mak Halliday, as Halliday said that social semiotics focusing on a field of discourse, tenor of discourse and mode of discourse.

\section{Results and Discussions}

Cultural hegemony is a form of mastery, domination, doctrine through cultural channels by the dominant (western) to the inferior (Indonesian society) massively with the help of the media as a form of the extended arm of global capitalism itself. Various cultures enter voluntarily and in turn will become fanatical about the culture of the intended community. The term westernization and even Americanization often appears to be a pilot of western culture in various parts of the east. One of the western and American cultures spread in Indonesia is music.

The West and America who adopt the liberalism system with an economic base can certainly uphold the values of freedom of expression and innovation, especially in the field of music. This is evidenced by the growth of industry and art music in the West and America. Many musicians (bands, duos, singers) with a variety of musical genres have sprung up and become a world trend and a music barometer in the world.
History of Western Music Hegemony and Counter Hegemony in Indonesia

Without realizing it, not long after Indonesian independence, western music has slipped into Indonesia since the 1950 s, the term sneaking became suitable when at that time, Indonesian foreign policy tried to stand in the middle by carrying out a non-aligned political system, in which Indonesia tried to remain neutral in the cold war between America and the Soviet Union. However, western influences, especially America, seem to be more dominant than those of the Soviet Union until Western music enters Indonesia:

\begin{abstract}
"Western music began to enter Indonesia in the 1950s through radio. At that time the condition of Indonesia choosing non-bloc in the cold war, at first it seemed that it did not want to side with one power and wanted to be neutral. But with such great power possessed by America, moreover America has emerged as a winner in the cold war, its influence on developing countries is very strong and cannot be denied "(Impani, 2018).
\end{abstract}

The swinging of Western music to Indonesia at that time was not without concern. The then Indonesian President Soekarno was deeply concerned about the likelihood of the Indonesian people being lulled by western music which could blunt the creativity of the Indonesian people:

\footnotetext{
"Soekarno, as the president at that time, was concerned about this phenomenon. He had far ahead thoughts, starting from music which he considered to be one of the spreaders of Western culture which will gradually lull the Indonesian people with its charm and a more violent one which will blunt the creativity of the Indonesian people "(Impani, 2018).
}

Sukarno's thoughts are now popularly known with the term pop culture, a massive culture, trend culture, mass culture, popular culture which is incidentally a culture of joining it so that it eliminates national identity. And the most important thing is the eradication of the creativity and imagination of the Indonesian people because it has fallen asleep with this popular culture. Lulled by following the existing (which has become a trend) is actually deliberately created by global capitalism.

The entry of western music into Indonesia quickly spread and became a trend, resulting in a massive appearance of English songs by Indonesian bands. The names of the bands also use foreign terms and so on. Western music fever at that time gave birth to a counter-hegemony form from Indonesia in the form of a policy prohibiting all things that originated from the west or that 
smelled western in Indonesia's music sector; starting from the prohibition of playing western music and so on. As revealed by Fadillah (2012) like the following:

"On that basis, Sukarno made a policy banning everything from the West, including players of Western music. Indonesian musicians were banned from playing English songs. Since then, many Indonesian bands which originally used English to name their bands have changed their name into Indonesian and sang Indonesian pop songs."

The prohibition of all western cultures in the Soekarno era is confirmed by relatively strict sanctions imposed on those who were stubborn to sing western songs called by Soekarno "ngak-ngikngok" music. Ngak-ngik-ngok is term used to describe a western music with rock $\mathrm{n}$ roll genre, such as Elvis Presley and the Beatles, who were very famous in the 1950s in Indonesia. They were subject to subversive law and even the police and the military could arrest them, as expressed by Fadillah (2012) as follows:

"Soekarno increasingly banned Western culture. Local music groups, let alone foreign music ones were banned from singing 'ngak-ngik-ngok' songs. Do not try to play music carelessly, otherwise. the culprit could be charged under subversive law. Police and soldiers were ready to catch those who tried to be stubborn."

The protection of national culture in the Soekarno era was very strict. Western culture was seen as the entrance of various kinds of hedonic cultures to Indonesia. The government at that time did not want a hedonic culture from the west to brainwash Indonesian youths. To further explore how stringent was the policy of the Soekarno government can be observed through: (1) imprisoning Indonesian band groups singing west songs. One of the imprisoned band groups was the Koes Bersaudara band (now called Koes Plus); (2) banning Indonesians from following the hairstyles of the British band, the Beatles; To carry out the ban police officers conducted tight raids by carrying scissors to shave bales of young men caught in the hairstyle of the Beatles, especially John Lennon; (3) prohibiting young men dressed in western style, especially tight pants. What is interesting is the strict proof of whether or not a soy sauce bottle can be put into the pants, if the ketchup bottle cannot enter the pants in the strict category and cut to the thigh. This is as stated by Fadillah (2012) as follows:

"The Koes Bersaudara Band Group (later named Koes Plus), was jailed for singing this song considered ngak-ngik-ngok. While in the prison,
Tony Koeswoyo created a song titled Ke Jakarta Aku kan Kembali. This song has been popular until now. Soekarno prohibited Indonesian youths not only to sing songs but also to have a haircut from the Beatles. The police also brought scissors to shave bald patches of young people who cut hair like John Lennon Cs. Not enough about haircut, Soekarno also banned young men from the tight style of the English musicians. The police again raided with scissors. It's easy. the police carried a ketchup bottle, if it turns out that the bottle can't fit into the pants, then the pants are considered tight. "Kresss!!" pants cut to thighs".

After the Soekarno government changed, resistance to western culture, especially western music did not happen again. Slowly but surely, western music came in with a smooth bombardment of Indonesia very quickly.

Sen \& Hil (2006) also stated that the development of music in Indonesia cannot be separated from government intervention and involvement. Text in music is also often disciplined by the government; for example, when a dangdut show sponsored by the Indonesian armed forces is used as a campaign tool; then performance of musicians like Iwan Fals is often prohibited because the audience is often chaotic and the lyrics are often considered to be against or criticism of the government.

At the political economy level, a strategy is needed. Khadavi (2014) explains the strategies used by the market in introducing pop music ideology to society, including three elements, namely standardization, homogenization and commodification. Standardization means everything that has been standardized based on general criteria. Standardization based on general criteria will easily be accepted by society. Homogenization means uniformity: the tastes, attitudes, styles and mindsets built by a large industrial system. Meanwhile, commodification is that all forms of cultural products must be tradable. The profit motive determines the nature of various cultural forms.

\section{West Java KPID Resistance to Western Music Hegemony}

The policy stated in the West Java KPID's decision number 480.215/KPID/West Java/2019 is actually to limit the display of 17 western songs at certain hours in West Java, instead of prohibiting the total screening. This policy was made after the West Java KPID has received a lot of inputs from the public since January 2018. In total, there were 52 complaints and 36 monitored items, all of which were English songs, The West Java KPID then conducted a study. As expressed by Dedeh Fardiah, chairman of the West Java KPID: "we conducted a 
study on western songs based on monitoring and public complaints." (Fikri, 2019).

In its study the West Java KPID found 86 English songs containing vulgar elements which are against the regulation. In response to the finding, the West Java KPID held a plenary meeting where it shortlisted the 86 songs to only 17 songs subjected to restrictions on their broadcasting. "The 86 songs were shortlisted to 17 songs. They are all western songs. This is (similar to) the case of dangdut songs in 2016. But now they are all western songs" (Fikri, 2019). In terms of social semiotics Halliday, the field element of discourse is about the restriction by the government (West Java KPID) on the broadcasting of the 17 western songs.

Civil Society Concerning the Resistance of the West Java KPID to Western Music Hegemony in West Java

In terms of social semiotics Halliday, the coverage by the five online media sites from the tenor of discourse was very clear about the elements of political society. In this case, West Java KPID as a regulator has received many attacks and antipathy from civil society, radio station managers, music directors and music observers; because the policy is not based on strong data such as research results.

Various public reactions to the restriction on the broadcasting of 17 songs emerged, including those from the radio industry. Andrie Ruliansyah, the station manager of B-Radio, planned to seek clarification from the West Java KPID shortly after learning the restriction on the broadcasting of 17 songs: "we want clarity on what is the basis (of the restriction) and whether (the restriction affects) lyrics or video clips. We don't know what are the parameters." Furthermore, Andrie also wanted to ask for further explanations about the segmentation of radio audience. He said the audience of his radio is adults so that the generalization of restriction is considered ambiguous: "our radio is for adults, so it's a bit confusing. What kind of explanation do we need" (Fikri, 2019).

Similar reactions also came from Gusti Sukma Prata, the music director of Hard Rock and I Radio Bandung. Prata protested against the restriction by stating that KPID West Java had made a mistake since it did not disseminate the restriction before issuing the circular. According to Prata: "as a person who works for the radio, I object to it and the KPID is wrong because it did not disseminate it. In fact, there is a music director association and the KPID team should be informed in advance". Prata further emphasized that the West Java KPID circular would turn off the radio in
Bandung on the grounds that the radio listeners who want to ask for the 17 songs will be disappointed and opt to digital. Prata argued that children today are more inclined to hear digital radio like Spotify and others. As Prata stated as follows: "today children listen to it digitally on Spotify and Youtube, can the KPID limit the media? The radio must broadcast top 40 songs and ads. If it's now limited and radio listeners can't request, this means that the radio is disappointing and the listeners will switch to digital" (Susanti, 2019).

The momentary response from the radio industry players who had negative tendency was reinforced by the response from one of the music observers in West Java, namely Idhar Resmadi. Idhar explicitly assessed that this restriction was quite strange and even had no clear basis: "I said this is quite strange and unclear, there should be a clear basis for which this policy can be made" (Dellanita, 2019).

Furthermore, Andrie Ruliansyah, station manager of B-Radio Bandung, also explained that musicians rejected the article in the Draft Bill. One of them concerns the restriction. "What is the restriction on radio? But they can still access YouTube and so on, which is much more like the video clip," said Andrie (Merdeka, 2019).

Idhar's resistance is also increasingly visible when stating that the song lyrics contained in music are clearly different from series or films that have visual power so that they can have a greater influence. Unlike song; song lyrics can be interpreted differently so it is very possible if the vulgar songs can be interpreted differently or just plainly for others: "The lyrics of the songs have multi interpretations, can I just say this song is vulgar in the lyrics. Others can think it's normal right".

Furthermore, Idhar also affirms resistance to the restriction by stating that if the KPID limits the broadcasting of these songs it must be based on strong evidence, a behavior al evidence that has occurred. For example, there should be clear evidence such as a man who raped a woman because he heard certain song lyrics, please forbid the song. If there isn't anything for what it is, it's not clear (Dellanita, 2019). Of course, the reason for the behavioral evidence that has taken place is considered quite reckless because the big purpose of the restriction is a preventive form before negative behaviors arise. The clear reason for KPID is also expected by Idhar. At the cultural level, KPID's resistance can be said to be a form of protection. Protection of local culture (Sunda), especially Sundanese music which over time can be eroded by western music culture. 
In terms of social semiotics Halliday, from the mode of discourse element; it can be seen that five online media sites demonstrate a lack of public support for the West Java KPID policy. The use of language that tends to question and criticize this policy shows how the media has succeeded in producing an image of rejecting the restriction on the broadcasting of 17 western songs.

From the data presented above, the music hegemony in the country has been going on for quite a long time, since 1960 where the west as the dominant class took control of the Indonesian people as a lower class. As stated by Rachar (2016) that "hegemony is a practice of various strata possessing or seeking state power, whereas dominance is primarily on coercion".

Although there had been a counter hegemony since Soekarno's time which was quite hard, western music hegemony wandered freely until now. Hence, the Indonesia masses as hegemon class accepted and even supported the hegemony by resisting the restriction on the broadcasting of western songs in West Java. This can be referred to as an attempt of resisting the hegemony itself.

It can be said that the counter hegemony carried out by the West Java KPID tends to be weak. As suggested by Gramsci, a strong counter hegemony strategy will work when the hegemon class is in the state of crisis. Here, the researcher does not see any crystalline hegemony that is strong enough in the western music industry, especially the American music industry. Even though Korean music begins to overwhelm Indonesia, the Western and American music industries still become the world's music promoters. Furthermore, Gramsci also stated, besides the element of crisis hegemony that occurs in the hegemon class, the element of war of position becomes very strategic (Gramsci 1975):

"Detailed process of counterpart as: (1) Hegemony Crisis, which can happen because of the threat of comfort in the interest of opposition class, or because of the difficulty in controlling and keeping the situation through legal action. (2) War of position, is a continuous counter towards super-structural culture for industrial developing countries. "The capitalist leaders use their power to defend their status in the society"

The mechanism of the war of position at the counter hegemony carried out by the West Java KPID which was also investigated did not occur because of the lack of superstructure in the form of civil society and political society that supported the counter hegemony. Instead of supporting the civil society, both elements of broadcasting practitioners, music observers even resisted counter hegemony carried out by the West Java KPID. The powerless counter hegemony carried out by the West Java KPID will in turn confirm and strengthen the hegemony itself (western music hegemony in West Java).

\section{Collaboration Between Political Society and Civil Society}

In regard to the restriction on the broadcasting of 17 western songs by West Java KPID, the researcher does not see any collaboration between political society; in this case the KPID, and civil society, especially musicians in West Java. Civil society has shown resistance to the West Java KPID policy. Of course, this is not in line with Gramscian thinking in creating a counter hegemony. Collaboration and cooperation between political society and civil society are essential in the counter hegemony; so that it becomes a great resistance force for the hegemon class, namely western music.

When there is no strong resistance, it is impossible to reach the stage which Gramscian calls a war of position, namely a strategy of resistance by encircling the hegemon class by creating various kinds of mass organizations of hegemonic class and by building and developing a hegemonic class culture. As stated by Ikhsano (2020). the war of position is based on the idea of besieging the state apparatus with a counter hegemony created by the mass organizations of the working class and by building institutions and developing a proletarian culture.

\section{Conclusions}

Resistance, as the counter hegemony carried out by West Java KPID by restricting the broadcasting of 17 western songs, to western music hegemony in West Java can be said to be unsuccessful. The crisis of hegemony, as one of the conditions for counter hegemony, is not fulfilled. In this study, there was no significant crisis in western music hegemony. Furthermore, in an effort to counter hegemony, Gramsci also emphasized the importance of war of positions by relying on mature strategies thanks to the collaboration between elements of civil society and political society.

Even this researcher thinks that this has not happened yet. What happened was that civil society should support and act as an agent, activists in carrying out the counter hegemony instead of defending openly and brightly the hegemony and resisting the counter-hegemony movement by the West Java KPID. Hence, the counter hegemony was made to become defiant and unsuccessful. Counter counterfeit hegemony itself actually 
shows that it is not structured and neat and there is no collaboration between the civil society and political society of the hegemon class which in turn confirms and exemplifies western music hegemony in West Java itself.

For this reason, it is very necessary to have a systematic and completed plan and of course, a strong collation of political society, which consists of KPID, central KPI, regional government and the central government and civil society consisting of the public, music industry and observers. Hence, the counter hegemony will run well to undermine hegemony.

\section{References}

Ali, N.G. (2015). Reading Gramsci through Fanon: Hegemony before Dominance in Revolutionary Theory. Journal Rethinking Marxism-A Journal of Economics, Culture \& Society, Volume 27 pages: 241-257. Retrieved from https://doi.org/10.1080/08935696.2015.100 7793

Arief, T.M.V. (2019, February 26). Penjelasan KPI Jabar Soal Pembatasan Siaran 17 Lagu Asing. Retrieved from https://kumparan.com/@kumparannews/pen jelasan-kpi-jabar-soal-pembatasan-siaran17-lagu-asing-1551177285272992005.

Berto. A. (2018). The Capitalization of Backpacking Tourism Culture in Indonesian Films. Jurnal Komunikasi Ikatan Sarjana Komunikasi Indonesia, 3(1), 1-11. Retrieved from https://doi.org/10.25008/jkiski.v3i1.143

Dellanita, A. (2019, February 26). Ini Kata Pengamat tentang Larangan Lagu Barat oleh KPID. Retrieved from https://www.ayobandung.com/read/2019/02 /26/45807/ini-kata-pengamat-tentanglarangan-lagu-barat-oleh-kpid

Fadillah, R. (2012, May 23). Jika Masih Ada, Soekarno Mungkin Larang Konser Lady Gaga. Retrieved from https://www.merdeka.com/peristiwa/jikamasih-ada-soekarno-mungkin-larangkonser-lady-gaga.htm

Fikri, A. (2019, February 27). Dianggap Cabul KPID Jawa Barat Batasi Jam Tayang 17 Lagu. Retrieved from https://bisnis.tempo.co/read/1180100/diangg ap-cabul-kpid-jawa-barat-batasi-jamtayang-17-lagu/full\&view $=$ ok

Gramsci, A. (1975). Letter From Prison; Selected, Translated From Italian, and Introduced by Lynne Lawner, Jonathan Cape. London: Thirty Bedford Square.
Ikhsano, A., Stellarosa, Y. (2015). The Resistance of Hollywood Movie Hegemony in Indonesia: Gramscian Analysis on Indonesian Tax of Imported Movies. TIIKM Journal of Film, Media and Communication, 1(1), 12-19

Ikhsano, A. (2020). Melawan Hegemoni Perfilman Hollywood. Tangerang: Indigo Media.

Impiani. D. (2018, Agustus 16). Hegemoni Musik Amerika. Retrieved from https://suakata.com/hegemoni-musikamerika/

Khadavi, M.J (2014). Dekonstruksi Musik Pop Indoensia dalam Perspektif Industri Budaya. Jurnal Humanity, 9(2). Retrieved from http://ejournal.umm.ac.id/index.php/humani ty/article/view/2392

Merdeka. (2019, February 28). Respons Praktisi Penyiaran Menyoal KPID Jabar Batasi Jam Siar 17 Lagu Asing. Retrieved from https://www.merdeka.com/peristiwa/respon s-praktisi-penyiaran-menyoal-kpid-jabarbatasi-jam-siar-17-lagu-asing.html.

Rachar, M. (2016). Power, Hegemony, and Social reality in Gramsci and Searle. Jounal of Political Power, 9(2), 227-247. Retrieved from

https://doi.org/10.1080/2158379X.2016.119 1222

Robinson, W.I. (2006). Gramsci and Globalisation: From Nation-State to Transnational Hegemony. Journal Critical Review of International Social and Political Philosophy, 8(4), 559-574. Retrieved from https://doi.org/10.1080/1369823050020524 3.

Rupert. M. (2006). Reading Gramsci in an Era of Globalising Capitalism. Journal Critical Review of International Social and Political Philosophy, 8(4), 483-497.

Sen, K. and Hill, D. T. (2006). Media, Culture and Politics in Indonesia, Jakarta: PT. Equinox Publishing Indonesia.

Stellarosa, Y. (2017). Woman Image in "Miss Jinjing Belanja Sampai Mati” Book. Jurnal Komunikasi Ikatan Sarjana Komunikasi Indonesia, 2(2), 97-108. Retrieved from https://doi.org/10.25008/jkiski.v2i2.108 
Susanti, L.A. (2019, March 1). KPID Jawa Barat Batasi Penyiaran lagu Berkonten Vulgar, Berikut Tanggapan Bruno Mars Hingga KPID. Retrieved from https://palu.tribunnews.com/amp/2019/03/0 1/kpid-jawa-barat-batasi-penyiaran-laguberkonten-vulgar-berikut-tanggapan-brunomars-hingga-kpid?page $=4$

Pikiran Rakyat. (2019, March 1). Ini Tanggapan Ridwan Kamil terkait Pembatasan Lagu Oleh KPID. Retrieved from https://www.pikiran-rakyat.com/jawabarat/2019/03/01/ini-tanggapan-ridwankamil-terkait-pembatasan-lagu-oleh-kpid. 